\title{
Consideration on the phenomenon of authority within the framework of constructivism
}

\begin{abstract}
Nilgün DAĞ $\breve{G}^{*}$
ABSTRACT. This article discusses the evaluations on the phenomenon of authority, within the framework of constructivism. First, the notion of authority is examined under phenomenal context; then, the incompatibility of the concept of authority, presumed by the constructivist approach which has been put into operation in 20052006 school year with the social structure and values of this land, was mentioned. Also, the thesis of transforming our understanding of authority and creating an alienation to the authority would cause problems due to this approach, with respect to our cultural texture was asserted. Suffocating hegemony of authority versus antiauthoritarianism are discussed with both their positive and negative aspects.
\end{abstract}

Keywords: Authority, constructivism, government, power.

\footnotetext{
${ }^{*}$ Lecturer, Sinop University, Faculty of Education, Department of Elementary Education, Sinop, Turkey. E-mail: nilgundag@yahoo.com
} 


\section{SUMMARY}

Purpose and significance: This article discusses the considerations on the phenomenon of authority, within the framework of constructivism. The notion of authority which is one of the controversial subject of many disciplines such as law, politics, ethics and education due to the fact that it brings into question the conflict between its aspect of obedience responsibility and freedom and individual autonomy which is completely contrary to the first one is analyzed within a factual context in the paper. Then, the incompatibility of the concept of authority -presumed by the constructivist approach which has been put into operation in 2005-2006 school year- with the social structure and values of this land, will be mentioned. Also, the thesis of transforming our understanding of authority and creating an alienation to the authority would cause problems due to this approach, with respect to our cultural texture will be asserted. Suffocating hegemony of authority versus anti-authoritarianism are discussed with both their positive and negative aspects.

Method: This study is a theoretical-oriented research. The notion of authority which is the subject matter of the research is studied to be intellectualized within the context of constructivism.

Results: Student is the creator of his own values by force of the constructivism understanding built on individualist and relativist structure of the western culture. Teacher has a position which shares authority with students and remains passive before the will of student. The loss of value experienced by teacher with regard to authority in a learning environment is not only the fact that subjectivity/individuality of student wins against teacher or system. At the same time, it means that teacher's authority decreases irreversibly. However, teacher should have a moral authority image more than anything else in a learning environment. In this paper, it is interpreted that necessity of authority in a class is organic and authority relation between a teacher and a student is a natural partnership and a source of solidarity due to its being organic. The individualism which is the basic axis of constructivism may transfer to a paradoxical form by the reason of the fact that student regards himself as the basis of all normativeness. In further stages, it may be faced with that any kind of value judgment shapes through individual perspective and ethical decision/judgment making mechanism is lost. This circumstance exposes us to some risks with respect to families, schools, institutions and state. 


\title{
Yapılandırmacılık Bağlamında Otorite Olgusuna İlişkin Tespitler
}

\begin{abstract}
Nilgün DA $\breve{G}^{*}$
ÖZ. Bu makale, yapılandırmacılık bağlamında otorite olgusuna ilişkin tespitleri konu almaktadır. Makalede, önce otorite mefhumu olgusal bağlamda incelenmekte; ardından 2005-2006 eğitim-öğretim yılında ülkemizdeki tüm ilköğretim okullarının birinci kademesinde uygulamaya konan yapılandırmacı yaklaşımın öngördüğü otorite anlayışının bu toprakların sosyal yapısı ve değerleriyle uyuşmadı̆̆ı ve bu yaklaşım gereğince otorite anlayışımızı başkalaştırmanın ya da otoriteden uzaklaşmanın toplumsal ve kültürel dokumuz açısından sorun oluşturacağı tezi ileri sürülerek otoritenin boğucu hâkimiyeti ile otorite karşıtlığ 1 olumlu ve olumsuz bir çerçeveden tartışılmaktır.
\end{abstract}

Anahtar Sözcükler: Güç, iktidar, otorite, yapılandırmacılık.

\footnotetext{
* Öğrt. Gör., Sinop Üniversitesi Eğitim Fakültesi İlköğretim Bölümü Sinop, Türkiye. E-posta: nilgundag@yahoo.com
} 


\section{GíRiş}

İnsanlığın en kadim zihniyet çerçevelerinden birisinin "ataerkillik" olduğu genel kabul gören bir görüştür. Bu görüsse göre her ataerkil toplum, tarih boyunca kendi kültürüne özgü hegemonik bir kutsal yaratmış ve bu kutsalı olgusal bir zemine yerleştirmiş̦tir. Özgürlüğü yasalarında, kurumlarında ve hayat tarzlarında savunmaya özen gösteren Amerikan toplumu için bu kutsal, "özgürlük" mefhumu olmuştur. "Eşitlik ülkesi" olarak anılan Fransa için ise temel dinamik, "eşitlik" mefhumudur (Leaman, 2010). Fransız İnsan ve Yurttaş Hakları Beyannamesi'nin her türlü ayrıcalıklara karşı insanların eşitliğine vurgu yapan bir özelliğe sahip olması bu bağlamda yersiz değildir. Türk toplumu için bu kutsalın, "otorite" olgusu olduğunu; ancak bunun "kendini bütünleyen bir otorite" anlamı taşıdığını söyleyebiliriz. Çünkü bu topraklarda, tarih boyunca bireyin hak ve özgürlükleri yerine, kurumsal otoriteye vurgu yapan bir siyaset ve hukuk anlayışı egemen olmuştur ${ }^{1}$. Bu egemen anlayışın izlerini, devlet geleneğinden dini inançlarımıza kadar birçok farklı alanda görmemiz olasıdır.

Osmanlı İmparatorluğu, otoritenin egemen olduğu bir imparatorluktur ve devlet otoritesine bağlllık aile yaşamının doğurduğu ve gerektirdiği bir davranıştır. Yani, otorite ile bireyin ya da toplumun özgürlüğü arasında pratikte asimetrik bir ilişki söz konusu değildir. Bu yönüyle otorite, toplumun kurucu ve taşıyıcı unsuru olup iktidara karşı toplumsal olarak oluşturulan bir sevgi ve saygı durumunu yansitan temel dinamiktir. Osmanlı için evrensel kavram ifadesinin dışında, özel bir anlam da ifade eden otoritenin $^{2}$ bu olumlu niteliği, destanlarla ${ }^{3}$ ve müziklerle ${ }^{4}$ de övülmüştür. Ancak bugün geldiğimiz noktada, gerçekliği tamamen bireysel bir temelde üreten ve meşrulaştıran -yapılandırmacılıkla eğitim sistemimize dâhil olanrölativist zihniyet, otoritenin karşısına "bir tavır alış" sendromu ile çıkmakta ve onu bireysel ve toplumsal yaşam alanından uzaklaştırmaktadır. Nasıl ki her insan dünyaya atalarından aldığı ırksal, dinsel, cinsel, sosyal vb. özelliklerle geliyorsa ve tüm bunlar dünyaya onun kim olduğu hakkında bir şeyler söylüyorsa, toplumsal dokular da insan karakterleri gibidir; parçalandığında antropolojik dayanağı zayıflamaktadır.

${ }^{1}$ Bunun temel sebebi, Türklerin sahip olduğu "Devlet-i Ebed-Müddet" fikriyatıdır. Bu fikriyata göre, devletin yönetim biçimi ya da iktidar değişse bile devlet hakimiyetinin süreklilik arz etmesi esastır.

${ }^{2}$ Osmanlı'daki otorite, idarenin otoritesi olduğu kadar ahlâkın, örf ve adetlerin de otoritesidir. Osmanlı dönemindeki sosyal hayat, yapı ve kurumlar ile gündelik yaşam pratikleri incelendiğinde, otoritenin bir toplum realitesi olarak sosyal hayattaki davranışları da tayin eden organik bir unsur olduğu netlikle görülebilecektir.

Türklerdeki cihan hakimiyeti ülküsünün Oğuz Kağan Destanındaki akisleri, Selçuklu ve Osmanlılarda da değiş̧memiştir. Ancak İslâmi bir mahiyet kazanmıştır.

${ }^{4}$ Devlete sadakat ve otoriteye saygı, Osmanlı geleneğinin bir parçasıdır ve bu geleneği mehter müziğinde görmek mümkündür. 
Toplumsal dokumuzun önemli köşe taşlarından biri olan otorite olgusunun rotasını belirlediğini düşündüğümüz Ehl-i sünnet anlayışına göre ise, devlet başkanı günahkâr da (fâsık) olsa ona itaat etmek gerekmektedir. "Sizden olan ulû'l-emre itaat edin" (Nisâ 59) ayet-i kerimesi ve bir Ehl-i sünnet bilgini olan Gazzâlî̀nin "Zalim de olsalar devlet adamlarına hakaret etmek doğru değildir" (DİB, 2011) sözü ${ }^{5}$, bu anlayışı özetler niteliktedir.

Netice itibarıyla, her toplumda farklı şekillerde karşımıza çıkan otorite temasının Türk toplumu için taşıdığı önemin bilincinde olarak ve 20. yy'ın en önemli siyaset felsefecilerinden olan Hannah Arendt'in “...gelenek, din ve otorite arasında en dayanıklı çıkan otorite olmuştur" (Arendt, 2010: 130) sözünü de referans alarak makalemizde, 2005-2006 eğitim öğretim yılında ülkemizdeki tüm ilköğretim okullarının birinci kademesinde uygulamaya konulan -ilköğretim programında benimsenen- yapılandırmacı yaklaşımın öngördüğü otorite anlayışının bu toprakların sosyal yapısı ve değerleriyle uyuşmadığı ve bu yaklaşım gereğince otorite anlayışımızı başkalaştırmanın ya da otoriteden uzaklaşmanın toplumsal ve kültürel dokumuz açısından sorun oluşturacağı tezini ileri sürerek otoritenin boğucu hâkimiyeti ile otorite karşıtlığını olumlu ve olumsuz bir çerçeveden tartışmaya çalıştık. Bunu yaparken mümkün olduğunca kavramsal ve dilsel çözümlemelere müracaat ederek betimleyici bir üslûp kullanmaya gayret ettik. Ülkemizde eğitim alanında yaptığımız ve yazdığımız çoğu şeyin deneysel olduğunu göz önüne aldığımızda, çalışmamızın teorik zeminde bazı tartışmalara ve açılımlara katkı sağlayacağını düşünmekteyiz.

\section{Otorite}

Otorite, karmaşık bir kavramdır. Klasik zamanlarda içtihat biliminin, ortaçağda dinin, modern zamanlarda ise siyaset ve toplumun düşünce tarihinde ortaya koyduğu çeşitli içerikler, onun karmaşıklığına yol açmıştır (Krieger, 1973). Bu sebepten ötürü kavramsal, ampirik ve teorik zeminde kabul edilebilen ve tüm tikel vakaları kapsayan bir otorite anlayışından söz etmek güç olmaktadır.

San (1971: 63)'a göre otorite, “başkalarının davranışlarını kendi isteklerine zorla uydurabilme olanağı"dır. Bu tanımın, içerik itibarıyla otoriteye karşılık geldiğini söylemek güçtür. Çünkü bu tanımda otoriter edimin, yöneldiği kişi ya da kişiler tarafından karşıtlıkla karşılandığı, yani iradi redde işaret etmesi sonucu o kişi ya da kişilere zor kullanma biçimine dönüştüğü vurgulanmaktadır. Dolayısıyla otorite uygulamak ile güç

\footnotetext{
${ }^{5} \mathrm{Bu}$ söz, en doğru hareket tarzının fâsık ve zâlim de olsa devletin meşru otoritesine baş kaldırmamak olduğunu vurgulamaktadır. Çünkü devlet adamının/hükümdarın varlığı (ehil olup olmadığı değil) anarşiden, keşmekeşten ve istikrarsızlıktan hayırlı görülmektedir.
} 
kullanmak, birbirini olumlayan olgular olarak görülmektedir. Kojéve'nin (2007), gücün kullanılması durumunda otoritenin söz konusu olmadığını şu örnek üzerinden açılayan satırlarına müracaat etmek isteriz:

"Eğer, birini odamdan çıkarmak için, güç kullanmak zorundaysam, söz konusu edimi gerçekleştirebilmek için, kendi tutumumu değiştirmek zorundayımdır ve böylece otoriteye sahip değilimdir; eğer hareket etmiyorsam ve bahis konusu kişi odayı terk ederse, yani benden gelen basit bir "çıkın" sözü üzerine değişiyorsa durum bambaşkadır. Eğer verilen emir bir tartışmaya, yani emri veren kişinin kendisinin verilen emre bağlı olarak bir şey yapmasına -tartışmasına- neden oluyorsa, otorite yoktur. Hele ki tartışma emirden vazgeçilmesine ya da hatta bir uzlaşmaya; yani tam olarak kendisi değişmeksizin, dışarıda bir değişime neden olacak diye kabul edilen edimin değişmesine varıyorsa." (2007: 15).

San'ın otorite anlayışı, iktidar olmanın üç yolu olduğunu savunan Öztekin'in (2000: 13) "otorite yoluyla iktidar olma" dediği şeye kısmen tekabül etmektedir. Bu bağlamda otorite mefhumunun, "iktidar" ve "güç" olguları ile karıştırıldığına vurgu yapmak isteriz. Güç, "bireylerin ya da grupların kendi çıkarları veya düşüncelerinin dikkate alınmasını, başkaları buna direnseler bile, sağlayabilme yeteneğidir" (Giddens, 2000: 361). Tanımdan da anlaşılacağı üzere güç, ancak diğer tarafin direnişinin üstesinden gelindiğinde var olmakta; bu bağlamda otorite zor kullanılmasını içermektedir. İktidar ise, karar alma, onu uygulama ve uygulatma gücünü ihtiva etmektedir. İçerisinde güç kullanma tekelini barındırsa da tarihi örnekler göstermiştir ki iktidar, salt güç tehdidinden ibaret değildir.

Her ne kadar iktidar ile aynı anlamı çağrıştırdığ düşünülse de otorite, en genel anlamıyla "yönetme hakkı" (Friedman, 1987: 28) olarak tanımlanmakta ve iktidarın özel bir biçimini -"meşru iktidar"1- ifade etmektedir. Öyle ki Sennett (2005: 26), "bir hükümet görevlisi belirli bir işte otoritesini kullanamadı" cümlesi ile bu iki kavramın farklı anlamlar ihtiva ettiğine dikkat çekmekte ve otoriteyi "iktidar koşullarını yorumlama, bir güç imgesi tanımlamak suretiyle denetim ve nüfuz koşullarına bir anlam verme çabası" (2005: 27) olarak tanımlamaktadır.

Arendt (2010: 129) ise, otoritenin bir tanımı yapilacaksa bu tanımın hem argümana dayanan "ikna" ile hem de güce dayanan "zorlama" ile bir karşıtlık içinde olması gerektiğine vurgu yapmaktadır. Arendt'in bu tanımının, otoritenin ne olmadığını belirten bir tarif olduğunu söyleyebiliriz. Çünkü ona göre otorite, dışarıdan gelen her türlü zorlayıcı aracın kullanılmasını yasakladığı gibi; argümanlara başvurulduğu yerde de kişinin itaat etme ve katlanma dışında bir şansının olmadığı bir heteronomi (otonominin tersi) durumunu da dışlamaktadır. Bu durumda, otorite nasıl mevcut olacak ve neyle beslenecek sorusu öne çıkmaktadır. Alman sosyolog 
Max Weber (1961; Akt: Gönenç, 2001: 134), bu hususta şöyle bir çözümleme yapmaktadır: "Tecrübelerimiz bize göstermiştir ki, hiçbir otorite sistemi, sadece maddi, duygusal veya ideal motiflere dayanarak sürekliliğini sağlayamaz. Bütün bunlara ek olarak, her otorite sistemi meşruiyetine ilişkin bir inanç oluşturmak ve beslemek gayretindedir.”. Bu çözümlemeye göre Weber'in otorite algısında, bir rejime ya da iktidara otorite sağlayan merkezi mefhum "meşruiyet" olup otoritenin mevcudiyeti ve sürekliliği meşruluğuna dair bir inanç oluşturmayı gerektirmektedir.

İnanç temelli bir meşruiyet tanımı yapan Weber, otoriteyi "belirli düzeydeki minimum gönüllü boyun eğiş" (Fried \& Amit, 2008: 56) olarak tanımlamakta ve meşruiyet kaynaklarına göre üç tip otorite biçiminden söz etmektedir. Geleneksel otorite, zamana bağlı olarak belli bir süreç içinde legal hâle gelmiş "kurumsallaşmış bir inanca" dayalı otoritedir. Bu otorite biçiminde temel olan şey, gelenek ve inançtır. Patrimonyal hükümdarın otoritesi ya da ana-baba ve yaşli otoritesi geleneksel otoritedir. Karizmatik otorite ise, olağanüstü ve Tanrı vergisi bir kişiliğin sağladığı mutlak itaat ve güvene dayanan otoritedir. Weberci terminolojide karizma sözcüğü, kendisine olağanüstü yetenekler atfedilen ve bu yönüyle de öteki sıradan insanlardan farklı olarak algılanan, aynı zamanda da toplumu bunalımdan kurtaracağına inanılan bireyleri tanımlamaktadır. Askeri ve siyasi liderler ve kahramanlar ile kendilerine ilâhi misyonlar yüklenen peygamberlerin otoriteleri, bu otorite tanımı içinde ele alınmaktadır. Toplumda bu otoriteye karşı teslimiyet, en üst düzeydedir. Kişilerden çok, yasalara ve rasyonel kurallara dayanan otorite türü ise, yasal-rasyonel otoritedir. $\mathrm{Bu}$ otorite tipinde, insanlar geleneksel olarak sayg1 gören bir şefe veya karizmatik bir lidere değil; bir dizi soyut, genel ve kişilik dışı kurala bağlılık göstermektedir. Modern dünyada geçerli olan otorite tipi, hukuki-rasyonel otoritedir (Weber, 2005: 133-134). Weber'in çözümlemesine göre siyasi iktidarı ellerinde tutanlar, yönetilenlerin rızasını talep ederken adeta şöyle seslenmektedir: Geleneksel şef: "Bana itaat et, çünkü halkımız yüzyıllardan beri şeflerine itaat etmiştir."; karizmatik lider: "Bana itaat et, çünkü ben senin hayatını değiştirebilirim."; hukuki-rasyonel yönetici: "Bana itaat et, çünkü ben senin hukuka uygun olarak atanan yöneticinim." (Weber, 1982; Akt: Gönenç, 2001: 134).

Weber, otoritenin tarihsel olarak üç aşamadan geçtiğini ifade etmektedir. Tarihin başlangıcından ortaçağa kadar olan süre içerisinde "geleneksel otoritenin”, orta çağdan sanayileşmenin başladığ 1 19. yüzyıla kadar "karizmatik otoritenin", 20. yüzyıldan itibaren ise rasyonel düşünceye dayalı "hukuki otorite" ile bilimsel bilgi destekli "uzmanlı otoritesinin" egemen olduğunu iddia etmektedir (Eroğlu ve İrmiş, 2004: 103).

Weber'den farklı olarak Kojéve (2007: 7-8, 23-24), tarihi süreç içerisinde dört ayrı otorite kuramından bahsetmektedir. Birincisi, ilk ve 
mutlak otoritenin Tanrı'ya ait olup diğer otoritelerin bunun türevi olduğunu iddia eden Skolastikler'in savunduğu "tanribilimsel (teolojik)" ya da "dinerkil (teokratik)" kuramdır. İkincisi, otoriteyi "adalet" ve "hakkaniyet" kavramlarına dayandıran "Platon'un kuramı"; üçüncüsü, otoriteyi bilgelikle kavramsallaştıran "Aristotales'in kuramı" ve dördüncüsü de otoriteyi "efendi-köle" ikilemine indirgeyen "Hegel'in kuramı"dır. Skolastik kuram, babanın (Tanrının) otoritesini izah ederken; Platon'un kuramına göre her otorite, "adalet" ve "hakkaniyet" üzerine dayanmaktadır. Reisin güruh üzerindeki otoritesi, Aristotales'in kuramına; efendinin köle üzerindeki otoritesi ise, Hegel'in kuramına denk düşmektedir (Kojéve, 2007: 7-8, 2324).

Netice itibarıla, otorite mefhumunun çok anlamlılığına ve bu konudaki görüşlerin birbirlerine belli ölçüde karşıt olmasına rağmen, otoritede "duygusal olarak hissedilen faal bir çekirdek" (Mendel, 2005: 31) vardır. Salt "eylemleri etkileme" anlamını değil; aynı zamanda başkalarının görüşleri üzerindeki "güç, entelektüel etki, inanç oluşturma kabiliyeti ve inanılmaya haklılık" anlamlarını da kapsamaktadır. Otoritenin bu ikinci anlamı bağlamında, otorite olarak adlandırılabilecek birçok ifade şekli (doktrinler, kişiler, fikirler, kitaplar gibi) vardır (Friedman, 1987). Bu bağlamda, otoritenin inançların $\mathrm{m}$ yoksa eylemlerin mi üzerine uygulandığ 1 sorusu, otorite mefhumunun muhtevası bakımından önemli bir sorudur.

\section{Türk Eğitim Sisteminde Otorite}

Türk Eğitim Sistemi, kökten ve acil bir dönüşüm ihtiyacı içindeydi. Çünkü pek çok alanda çağın gerisinde kalmış ve bilgi toplumunun gereksinim duyduğu bilgi ve becerilerle donatılmış bireyler yetiştirmede başarısız olmuştu. Bu durumun kaynağında, hem yapı hem program hem de öğretmen boyutundan kaynaklanan birtakım sorunlar vardır (Erdoğan, 2002). Özünde, tüm bu sorunlar birbiriyle ilintilidir ve neticede Türk Eğitim Sistemi'ni bu noktaya getirmiştir. 2005-2006 eğitim öğretim yılı itibarıyla, eğitimde referans alınan yaklaşım değiştirilerek ülkemizdeki tüm ilköğretim okullarının birinci kademesinde yapılandırmacı yaklaşımın temel alındığı yeni ilköğretim programı uygulamaya konulmuştur. Bu değişim hareketiyle birlikte öğretmen ve öğrenci rollerinin değişmesi, öğrenme ortamının teknolojik araç-gereçlerle desteklenerek zenginleştirilmesi, ölçme ve değerlendirme yöntem ve tekniklerinin farklılaştırılarak öğrenmede ürün temelli ölçme ve değerlendirmenin yanı sıra süreç temelli değerlendirmeye önem verilmesi gibi unsurlar, eğitim programlarının temel belirleyicileri hâline gelmiştir.

Bu unsurlardan öğretmen ve öğrencinin rolünü, Brooks \& Brooks'un (1999: 23) şu satırlarında bulmak mümkündür: "Yapılandırmacı öğretmen 
kuzey yıldızı gibidir, öğrencinin nereye gideceğini söylemez fakat yolunu bulmasına yardımc1 olur”. Öğretmenin gözlemci ve rehber; öğrencinin ise, özgür ve iradi yanına vurgu yapan bu satırlar, bazı noktaları sorunlu hâle getirmektedir. Batı kültürünün bireyci ve rölâtivist yapısı üzerine kurgulanan yapılandırmacı anlayış gereği öğrenci, kendi değerlerinin yaratıcısıdır. Öğretmen ise, otoriteyi öğrencilerle paylaşan ve öğrencinin iradesi karşısında pasifleşen bir konumdadır Oysa öğretmen, öğrenme ortamında her şeyden önce moral bir otorite imajına sahip olmalıdır.

Yapılandırmacılığın sembolizmden (simgecilik) solipsizme (tekbenciliğe) kadar uzanan oldukça geniş bir çeşitliliği barındırdığı (Şimşek, 2004: 117) göz önüne alındığında, solipsizm ucunda öğrencinin kendisini tüm normativitenin temeli olarak görmesi ile otoriteden tümüyle kopması ve öğrenme ortamında bir kaosun tetiklenebilmesi olası görünmektedir. Bu bağlamda yapılandırmacılığın temel aksı olan bireycilik, paradoksal bir biçime dönüşebilmektedir. Pozitif bir bakış açısıyla öğrenciyi nihai amaçsızlığa sürükleyebileceğinin; negatif bir bakış açısıyla ise, öğrenciyi bir yandan fanatizm ve mistisizm gibi metafizik teselli arayışlarına diğer yandan da nihilist ve kinist bir öğretiye götürebileceğinin altını çizmek isteriz. Zira özgürleşen öğrencinin otonomisinin sınıf içinde nasıl mümkün olacağı sorusu, sınıfı ikili yol ayrımından daha fazla sayıda yol ayrımıyla karş1 karşıya bırakabilecektir. Sınıflarda başlayan bu bilinmeyene yolculuk/belirsizlik ile tarih boyunca bir nesli diğer nesle bağlamada bize yol gösteren kılavuz ipini de yitirmiş olacağız ve belki de bir toplum türünden kültürel referansı değişmiş bir başka toplum türüne geçiş yapacağız. Unutmayalım ki, "Tarihin sedası hoş olmaktan çok gök gürültüsü gibi hacimlidir ve bitmeyen bir yankıyı andırır" (Ortayl1, 2006: 141).

Otoritenin bu topraklarda varlığını asırlardır sürdürdüğünü ve herhangi bir otorite boşluğunda toplumun kaosa sürüklendiğini göz önüne aldığımızda, Türk toplumunun özsuyunu oluşturan en temel özelliklerinden birisinin "otorite" olduğunu söylememiz yanlış olmaz. Türkler, otoriteyi dışlayan bir millet değildir ve otorite retoriğinin Türk toplumu açısından bir tarihi vardır. Gerek Cumhuriyet öncesi gerekse Cumhuriyet sonrası dönemde, otoriteye denk düşen üstünlük kabulü ne biat ederek köle olma ne de yadsıyarak ya da nefret ederek otorite karşıtı olma şeklinde anlaşılmıştır. Bizim otorite anlayışımız, en sade anlatımla öğretmenin öğrencilerin görüşleri üzerindeki "güç, entelektüel etki, inanç oluşturma kabiliyeti ve inanılmaya haklılık"la (Friedman, 1987) eşdeğer bir anlayıştır.

$\mathrm{Bu}$ noktada, şu paradoksa değinmemiz yerinde olacaktır. Otoriteye yönelik davranışlar ile otoriterizmle ilişkilendirilen kişilik değişkenleri arasındaki ilişkiyi teorik zeminde ispat etmek ve netleştirmek gerekmektedir. Çünkü otorite, doğası gereği "fail" (yapan) ile "meful" (işten etkilenen) 
arasında gerçekleşen bir ilişkidir ve özsel olarak bireysel değil; toplumsaldır. Yani, otorite olabilmesi için en az iki tarafın (fail ve meful) olması gerekmektedir. $\mathrm{Bu}$ bağlamda otorite sahibi insanların, diğer insanlar ve kendileri hakkında ne hissettiği önemli bir sorudur. Eğer otoriteye yönelik davranışların otorite sahibi kişiye yönelik davranışlar ile otorite sahibi olmayan kişiye yönelik davranışlar arasında pozitif (olumlu) bir ilişki olmadığı gösterilebilseydi, Rigby ve Rump (1979) tarafından önerildiği gibi, otoriteye yönelik davranış mefhumunun yeniden değerlendirilmesi ve belki de terk edilmesi gerekecektir (Rigby, 1986: 494). Rigby'nin bu tespitine göre, bir öğrencinin öğretmenine ve sınıf arkadaşlarına karşı olan tavırları arasında herhangi bir farklılık yoksa otorite diye bir kavramın varlığından söz etmemiz söz konusu değildir. Bu durumda yapılandırmacı yaklaşımın öngördüğü otorite anlayışı, otoriteyi özü itibarıyla sorunlu hâle getirmektedir. Çünkü otorite; kusursuzluk, küresellik, tartışmasızlık gibi farklı özellikler ihtiva eden "yüksek özlü bir düzen" varsaymaktadır (Mendel, 2005). Otoriteyi bu yüksek özünden azat ederek kavramsallaştırmak, kanaat önderini yok saymaya meyledebilecek ve Mendel'in deyişiyle "kişiyi farkında olmadan içinde yüzdüğü evren"den (2005: 32) kopararak Hobbes'un işaret ettiği şu sonucu verebilecektir:

"Bireylerin çoğunlukla doğru ve yanlış hakkında anlaşmazlığa düşmesi ve kendilerinin doğru ve yanlış hakkında en iyi yargılayıcı olduğunu sanmaları nedeniyle, bireylerin kendi kişisel yargılarının her şeyin üzerinde olduğuna dair kabulleri devam ederken doğru ve yanlış hakkındaki tartışma otoriter bir zemine çekilemez" (Akt: Uyanık, 2007: 18).

Birçoklarının itirazına maruz kalacak olsa da biz, Hobbes'un bu tespitini merkeze alarak otoritenin sınıftaki gereksiniminin organik olduğunu düşünmekte ve bu organiklik gereği, öğretmen-öğrenci arasındaki otorite ilişkisini doğal bir ortaklık ve bütünlüğün kaynăg 1 şeklinde yorumlamaktayız. Öğretmenin otoriteyi bir tahakküm biçimi olarak görmesi ve bunun bir yansıması olarak eylem ve söylemlerinin öğrenciler tarafından tabulaştırılarak onun totemik bir figüre dönüşmesi meselesinin ise, bir bilinçlilik sorunu veya otoriterizmle ilişkilendirilen kişilik değişkeni üzerinden yürütülmesi gerektiği kanaatindeyiz. Çünkü otoritenin kullanım şekli, büyük ölçüde öğretmenin kişilik ve karakter özelliklerine bağlıdır. Şüphesiz, içinde bulunulan durum da bu kullanım şeklinde etkilidir. Öyle ki bu hususta Milgram, "Kişinin nasıl davranacağını belirleyen genellikle onun nasıl bir kişi olduğundan çok, kendini içinde bulduğu durumdur" (1974: 205) diye yazmıştır.

Otoritenin sınıflarda nasıl müzakere edildiğinin incelenmesi ile ilgili üç teorik bakış açısı mevcuttur. Birincisi, demokrasinin bir yaşam türü olduğuna vurgu yapan ve öğrencilerin toplu düşünme ve müzakerelere aktif 
katılımını gerektiren Dewey'in (1966) "demokratik eğitim vizyonu"dur. İkincisi, otoritenin bir mülk gibi sahiplenilmeyen "ilişkisel bir yapı" olarak düşünüldüğü, fakat tecrübe vasıtasıyla sürekli akan bir güç olduğu ve karş1ıklı eylemler yoluyla ortaklaşa yapılandırıldığı için belirli eğitim uygulamalarına bakılmaksızın otoritenin sürekli müzakere edildiği Foucault'un (1980) “iktidar algısı”dır. Üçüncüsü, karşılıklılık ve diyalog ile karakterize edilen, hâkimiyet ile tanımlanan, demokrasi ve iktidar teorilerini birleştiren Freire'nin (1996) “özgürleştirici alışkanlıklar teorisi”dir (Brubaker, 2009: 100). Bu üç teorik bakış içerisinde, eğitim anlayışımızda 2000'li yıllara kadar Dewey'in "demokratik eğitim vizyonu” ağırlığını gösterirken 2000'li yıllardan sonra Foucault'un “iktidar algısı" ile Freire'nin “özgürleştirici alışkanlıklar teorisi”nin daha fazla öne çıktığını gözlemliyoruz. Dewey, Foucault, Feire gibi düşünürler, öğrencinin bireyselliğine bir özerklik işareti olarak saygı gösterilmesi gerektiğine vurgu yapmakta; öğretmenin öğrenciye müdahalesinin öğrencinin doğasını bozduğu gerekçesiyle, öğretmen ve öğrenci arasındaki ilişkiyi eşitlik temelinde kurmaktadırlar. $\mathrm{Bu}$ düşünceye göre otorite, ya paylaş1larak işlemekte ya da salt öğrenci tarafından temsil edilmektedir. Bu hususta biz, paylaşılması durumunda dahi öğretmenin otoritesinin yıprandığı, pedagojik olanın politik ve etik bir pratiğe dönüşerek sınıf bütünlüğünün tehlikeye düştüğü kanaatindeyiz. Çünkü bize göre öğretmen ve öğrenci arasındaki ilişki, özü itibarıyla hiyerarşiktir ve bu hiyerarşik konumu gereği otorite sahibi olması gereken öğretmendir. Öğretmen, meşru güç olmanın yanında uzmanlığ ile de bir otoritedir.

Öğretmenin sınıftaki hiyerarşik konumu için uygun görünen duygu niteliği ise, "saygı"dır; bu, "bir insanın değerinin bilinmesi veya kabul edilmesi” (Rigby, 1986: 494-495) anlamına gelmektedir. Sayg1 duygusunun, gündelik yaşamdaki eğilimlerden kaynaklanan duygulardan farklılığına ilişkin şu sözlerin çok anlamlı olduğunu ifade etmek isteriz:

"Saygının yokluğu, açıkça yapılan bir hakarete nazaran daha az saldırgan olsa da, aynı derecede yaralayıcı bir hal alabilir. Örneğin, karşıdaki insana hakaret edilmiyordur ama onun bir insan olarak varlığı da tanınmıyordur: $\mathrm{Bu}$ kişi, varlığı önem arz eden tam bir insan olarak görülmüyordur.

Bir toplum, yalnızca birkaç kişiyi ayırıp, geri kalan kitlelere bu şekilde davrandığı zaman bu bir saygı kitlığ yaratır. Sanki bu kıymetli cevherden herkese yetecek kadar yokmuş gibi. Çoğu açlıklar gibi, bu kıtlık da insan yapımıdır; yiyeceğin aksine saygının hiçbir maliyeti de yoktur. O zaman niçin saygı bu kadar kıt olsun ki??" (Sennett, 2005: 17).

Rigby (1986: 494), "otorite yanlısı kişiler, otorite sahibi kişiye nispeten üst düzey sayg1 göstermektedir; ancak otorite sahibi olmayan kişilere üst düzey bir sayg1 göstermemektedir" demektedir. Belki bu aşamada "doğal" 
ve "toplumsal" otorite mefhumlarına da değinmek gerekecektir. Şöyle ki doğal otorite, edinilebilen bir şey değildir; karizma ya vardır ya da yoktur. Toplumsal otoritenin durumu ise başkadır. Meşrulaştırıcı otoriteden kaynaklı resmi bir vekillikle işler ve kendisine toplumsal otorite yatırımı yapılmış olan geleneksel işareti (bir kostüm giymek ya da ayırt edici ve görünür bir amblem, rozet takmak, yargıcın ve üniversite profesörünün cübbesi, rahip cübbesi, subayın rütbe şeritleri, mübaşirin gümüş zinciri, trafik polisinin üniformas1, devletin dağıttığı nişan ve madalyalar) vardır (Mendel, 2005: 114). $\mathrm{Bu}$ mantığa göre bir sinıftaki öğretmen, Weber'in otorite terminolojisindeki üç otorite tipine de (geleneksel, karizmatik ve rasyonel) sahip olmalıdır.

\section{SONUÇ}

Otorite, bir yönüyle itaat yükümlülüğü sorununu; buna zıt olan diğer yönüyle de özgürlük ve birey otonomisi hakkındaki çatışmayı gündeme getirmesi ile hukuk, siyaset, ahlâk, eğitim gibi birçok disiplinin tartışmalı konularından birisi olmaktadır. Bu makalede biz, otorite anlayışımızı sosyal hafıza dinamiklerini göz ardı etmeden ortaya koymaya çalıştık. Bunu yaparken yapılandırmacı pedagojinin öne çıardığı öznellik arayışının, toplumsal ve kültürel yaşamdaki tüm norm ve değerleri izafileştirerek (görece hâle getirerek) bilinmeyene bir yolculuğa sürüklediğini gösterme gayreti içinde olduk. Otorite konusunda öğretmenin yaşadığı değer kaybının, salt öğrencinin öznelliğinin/bireyselliğinin öğretmene ya da sisteme galip gelmesinden ibaret olmadığını; bunun aynı zamanda öğretmenin otoritesinin geri dönülmez bir şekilde düşüşe uğraması demek olduğuna da dikkat çekmeye çalıştık.

Bugün okullarımızda şiddeti gözden düşürmüş, sıfir hoşgörü pedagojisini rafa kaldırmış, bireyi sınırlayan her türlü tavra karş1 okullarımızı daha özgür ortamlar hâline getirmede önemli bir yol almış olsak da bireysel düzlemde gerçekleştirmeye çalıştığımız bu değişim hareketlerinin toplumumuzun temel dinamiklerinden biri olan otorite temasını önemli ölçüde manipüle ettiği noktasında Arendt'in vardığı bu tespite katılmamamız elde değildir. "Birey"in yaşamın her alanında baş aktör kabul edilmesi, her türlü değer yargısının onun bakış açısından şekillenmesine ve ahlâki karar/yarg1 verecek bir mercinin yitip gitmesine sebep olabileceği gözden kaçırılmamalıdır. Bilhassa, aile hayatımızdan düşünce ve fikir dünyamıza kadar hayatımızın birçok alanında kök salmış olan otorite şemasından kısmen veya topyekûn uzaklaşılmasının aileler, okullar, kurumlar ve devlet açısından doğuracağı riskler hesap edilmelidir. 2000'li yıllara kadar eğitim programını "konu" merkezli program tasarımı yaklaşımına göre inşa etmiş bir toplumun eğitim anlayışı ve 
örgütlenmesinin, postmodernizmin eğitimdeki karşılığı olarak nitelendirdiğimiz yapılandırmacı yaklaşımla beraber spekülatifleşmesinin doğurabileceği riskler üzerinde düşünülmelidir.

Bugün otoritenin yirmi yaşında olan bir genç için taşıdığ anlamla geçen yüzyılın ellili ve altmışı yıllarında yaşayan biri için taşıdığı anlam aynı değildir (Mendel, 2005). Zaman içerisinde otorite ilişkileri birçok yönden değişmiştir. Taşıdığı anlam ve kaynağı her ne olursa olsun otorite, insani ilişkilerinin tümünde rastlanan bir olgudur ve insanlar için tabiatın bir gereğidir. Arendt (1993: 95), gerek insan yaşamında gerekse politika alanında eylemleri yönlendiren belli türde bir otorite bulunması gerekliliğine işaret ederek "otoritenin yitimi dünyanın dayanaklarının yitimine denktir" sözüyle bu gereğe vurgu yapmaktadır.

\section{KAYNAKLAR}

Arendt, H. (1993). Between past and future: eight exercises in political thought. New York: Penguin Books.

Arendt, H. (2010). Geçmişle Gelecek Arasında (3. Baskı). İstanbul: İletişim Yayınları.

Blass, T. (1999). The Milgram paradigm after 35 years: Some things we know about obedience to authority. Journal of Applied Social Psychology, 29, 5, 955-978.

Brooks, M. G. \& Brooks, J. G. (1999). The courage to be constructivist. Educational Leadership, Vol: 57, No: 3, 18-24.

Brubaker, N. D. (2009). Negotiating authority in an undergraduate teacher education course: A qualitative investigation. Teacher Education Quarterly, 36, 4, 99118.

Diyanet İşleri Başkanlığı (2011). İlmihal II İslam ve Toplum [Internet-17.01.2011] http://www.diyanet.gov.tr/turkish/basiliyayin/weboku.asp?sayfa $=42 \&$ yid $=36$

Erdoğan, İ. (2002). Yeni Bir Bin Yıla Doğru Türk Eğitim Sistemi. İstanbul: Sistem Yayıncilik.

Eroğlu, F. \& İrmiş, A. (2004). Yönetim Krizlerine Karşı Yönetim Ahlâkının Yeniden İnşası. Türkiye Günlüğü, Sayı: 78, 102-109.

Fried, M.N. \& Amit, M. (2008). The co-development and interrelation of proof and authority: The case of Yana and Ronit. Mathematics Education Research Journal, 20, 3, 54-77.

Friedman, R. B. (1987). Authority. In David Miller, Janet Coleman, William Connolly, Alan Ryan (Eds.), The Blackwell Encyclopaedia of Political Thought (pp. 28). Oxford: Blackwell.

Giddens A. (2000). Sosyoloji (Çev: H. Özel \& C. Güzel). Ankara: Ayraç Yayınları.

Gönenç, L. (2001). Meşruiyet Kavramı ve Anayasaların Meşruiyet Problemi. Ankara Üniversitesi Hukuk Fakültesi Dergisi, Cilt: 50, Sayı:1, 131-152.

Kojéve, A. (2007). Otorite Kavramı (Çev: M. Erşen). İstanbul: Bağlam Yayıncılık.

Krieger, L. (1973). Authority. In Philip P. Wiener (Ed.), Dictionary of the history of ideas (Vol. I, pp.141-162). New York: Charles Scribner's Sons. 
Leaman, O. (2010). Özgürlük, Eşitlik ve Kardeşlik Ne Kadar Makul Bir Politik Slogandır?. Birinci Ulusla arası Felsefe Kongresi, 14-16 Ekim, Bursa.

Mendel, G. (2005). Bir Otorite Tarihi Süreklilikler ve Değişiklikler (Çev: I. Ergüden). İstanbul: İletişim Yayınları.

Milgram, S. (1974). Obedience to Authority. New York: Harper Torchbooks.

Ortaylı, I. (2006). Kırk Ambar Sohbetleri (4. Baskı). Ankara: Aşina KitaplarTurmaks Yayıncilik.

Öztekin, A. (2000). Siyaset Bilimine Giriş. Ankara: Siyasal Kitapevi.

Rigby, K. (1986). Acceptance of authority, self and others. The Journal of Social Psychology, 126 (4), 493-501.

San, C. (1971). Max Weber'de Hukukun ve Meşru Otoritenin Sosyolojik Analizi. Ankara: İktisadi ve İdari Bilimler Akademisi Yayınları.

Sennett, R. (2005). Saygl (Çev: Ü. Bardak). İstanbul: Ayrıntı Yayınları.

Sennett, R. (2005). Otorite (Çev: K. Durand). 2. Baskı. İstanbul: Ayrıntı Yayınları.

Şimşek, N. (2004). Yapılandırmacı Öğrenme ve Öğretime Eleştirel Bir Yaklaşım. Eğitim Bilimleri ve Uygulama, 3 (5), s.115-139.

Uyanık, H. (2007). Joseph Raz'da Hukukun Otoritesi Kavramının Temellendirilmesi. Yayınlanmamış yüksek lisans tezi, İstanbul Üniversitesi, İstanbul: Türkiye.

Weber, M. (2005). Sosyoloji Yazıları (Çev: T. Parla.). 7. Baskı, İstanbul: İletişim Yayınları. 